\title{
Rancang Alat Pendeteksi Golongan Darah Berbasis Arduino Uno
}

\author{
Dany Pratmanto ${ }^{1}$, Rousyati $^{2}$, Ratna Kurnia Sari ${ }^{3}$, Husni Mubarok ${ }^{4}$, Fitria Tisa' Tiffani ${ }^{5}$, \\ Fathurrohman Al Ubaidillah ${ }^{6}$ \\ ${ }^{1}$ Prodi Sistem Informasi, STMIK Nusa Mandiri Jakarta \\ ${ }^{2}$ Prodi Sistem Informasi, Universitas Bina Sarana Informatika \\ 3,4Prodi Sistem Informasi Akuntansi, Universitas Bina Sarana Informatika \\ ${ }^{5,6}$ Prodi Teknologi Komputer, Universitas Bina Sarana Informatika \\ 1dany.dto@nusamandiri.ac.id, 2rousyati.rou@bsi.ac.id, 3ratna.rus@bsi.ac.id, \\ 4husni.hub@bsi.ac.id, 5tiffani.tisa24@gmail.com, 6fathurrohmanalubaidillah@gmail.com
}

\begin{abstract}
Nowadays many medical devices are being created such as stethoscopes, thermometers, syringes and tensimeters which are increasingly sophisticated in order to facilitate the provision of health services. these tools are also made with the aim of helping human work, one of which is a medical device that is a blood type detector. Better than the LED sensor process as a transmitter and photodiode sensor as well as Anti $A$, Anti $B$, Anti $D$ serum, comparator circuit and data processing using Arduino Uno then the sensor will be processed and the results of group readings will be displayed on the $L C D$ screen. ABO. The workings of this tool are blood samples that are dropped by antisera and placed on preparations, and detected by an optoisolator and then the data from the optoisolator is transferred to Ardunio Uno which has been programmed to determine blood type. Then the results of the instructions that exist in this Arduino Uno microcontroller so that the direct output can be approved on the LCD and then the results of blood type examination that will be equipped with: blood type, which has been approved. use to be evidence for patients who have blood type checks at the clinic. in the design of this tool used $C$ language programming
\end{abstract}

Keywords: Making Arduino Uno-based Blood Type Detection Devices, ABO Method, Photodiode Sensors and LEDs

Abstrak: Sekarang ini banyak diciptakan alat-alat kesehatan seperti stetoskop, thermometer, alat suntik dan tensimeter yang semakin canggih guna memudahkan pemberian pelayanan kesehatan. alat-alat tersebut juga dibuat dengan tujuan untuk membantu pekerjaan manusia, salah satunya alat kesehatan yaitu alat pendeteksi golongan darah. Dimulai dari proses sensor LED sebagai transmitter dan sensor photodioda serta serum Anti A, Anti B, Anti D, rangkaian komparator dan pengolahan data menggunakan Arduino Uno kemudian sensor akan diolah dan hasil pembacaan golongan darah akan ditampilkan pada LCD display. Dirancang untuk mengetahui golongan darah manusia secara otomatis dan cepat menggunakan metode $A B O$. cara kerja alat ini adalah sampel darah yang telah ditetesi antisera dan ditempatkan pada preparat, dan dideteksi oleh optoisolator kemudian data dari optoisolator dikirimkan ke Ardunio Uno yang telah diprogramkan untuk menentukan golongan darah. Kemudian hasil dari instruksi-instruksi yang ada pada mikrokontroler Arduino Uno tersebut sehingga output nya langsung dapat ditampilkan pada LCD dan dicetak hasil pengujian golongan darah yang nanti nya tampilannya meliputi: golongan darah, yang telah diuji. gunanya untuk menjadi bukti untuk pasien yang telah melakukan pemeriksaan golongan darah di tempat klinik tersebut. pada perancangan alat ini digunakan bahasa pemograman bahasa $\mathrm{C}$

Kata kunci: Pembuatan Alat Pendeteksi Golongan Darah Berbasis Arduino Uno, Metode $A B O$, Sensor photodioda dan LED

This is an open access article distributed under the Creative Commons Attribution License, which permits unrestricted use, distribution, and reproduction in any medium, provided the original work is properly cited. (O2019 by author and IJSE-Indonesian Journal on Software Engineering. 


\section{A. PENDAHULUAN}

Perkembangan teknologi semakin hari semakin mengalami kemajuan di era globalisasi ini kemajuan teknologi telah mengalami kemajuan yang sangat pesat. Hal ini tidak dapat dipungkiri dikarenakan semua aspek kehidupan kini telah mendapatkan dampak dari kemajuan teknologi, salah satu nya aspek kesehatan. Saat ini dunia kesehatan semakin mengalami kemajuan yang sangat pesat karena dampak dari kemajuan teknologi tersebut. Sekarang ini banyak diciptakan alat-alat kesehatan seperti stetoskop, thermometer, alat suntik dan tensimeter yang semakin canggih guna memudahkan pemberian pelayanan kesehatan. alat-alat tersebut juga dibuat dengan tujuan untuk membantu pekerjaan manusia, salah satunya alat kesehatan yaitu alat pendeteksi golongan darah.

Penggolongan darah melibatkan dua tipe molekul yaitu antigen dan antibodi, untuk sistem penggolongan darah yang sering dipakai adalah sistem penggolongan darah $A B O$. Dalam sistem $\mathrm{ABO}$ ada atau tidak adanya antigen $A$ dan tipe $B$ pada sel darah merah untuk menentukan golongan darah tersebut, misal jika seseorang memiliki golongan darah A maka pada sel darah merahnya terdapat antigen $\mathrm{A}$.

Pada sistem $\mathrm{ABO}$ terdapat antibodi terhadap antigen yang tidak terdapat pada sel darah merah orang tersebut, antibodi ini disebut dengan anti -A dan anti -B.

(Melati et al., 2011) menyimpulkan bahwa :

Darah merupakan cairan yang bersirkulasi dalam tubuh manusia yang berfungsi untuk mengirimkan zat-zat dan oksigen yang dibutuhkan oleh jaringan tubuh, serta mengangkut bahan-bahan kimia hasil metabolisme, selain itu darah juga berfungsi untuk pertahanan tubuh terhadap virus atau bakteri.

Dalam dunia kedokteran golongan darah manusia dibagi menjadi empat yaitu $A, B, A B$, dan O. Pembagian ini dilakukan karena adanya perbedaan jenis karbohidrat dan protein pada permukaan membran sel darah merah. Untuk mengetahui jenis golongan darah seseorang perlu dilakukan uji laboratoriom. Selama ini untuk pengujian golongan darah sering digunakan metode $\mathrm{ABO}$, yang prosesnya dilakukan secara manual atau dengan cara meneteskan tiga jenis cairan atau reagen pada sampel darah. Jenis golongan darah sangat penting pada saat tranfusi darah, seseorang harus menerima darah dari golongan darah yang sama dengan pendonor. Dalam proses pengujian sampel darah menggunakan metode ABO, sampel darah akan diteteskan suatu reagen, kemudian pada sampel darah akan terjadi proses aglutinasi atau penggumpalan darah. Penggumpalan darah disebabkan karena adanya interaksi antibodi dengan antigen yang terikat pada eritrosit. Darah memiliki antigen dan antibodi, dimana setiap masing-masing antigen dan antibodi terdiri dari A dan B.

Pengujian dan pengamatan untuk menentukan golongan darah umumnya dilakukan dengan serangkaian percobaan pada sampel darah, yaitu melakukan reaksi antara cairan dengan sampel darah dan antisera. Perubahan yang terjadi dari reaksi tersebut adalah aglutinasi atau non-aglutinasi. Pengamatan reaksi ini biasanya langsung dilakukan oleh mata penguji, dan dari reaksi yang dihasilkan akan menentukan tipe golongan darah tertentu. Pengujian diatas harus dilakukan oleh orang yang berpengalaman sehingga keakuratan data yang diperoleh masih mengandalkan kemampuan mata penguji. Mata dipengaruhi oleh faktor kelelahan, sehingga cara ini kurang menguntungkan untuk pengujian sampel darah dalam jumlah yang banyak. Kesalahan dalam pembacaan golongan darah ini dapat menimbulkan masalah yang sangat serius bagi seseorang, misalnya dalam proses transfusi darah atau identifikasi keturunan. (Inggi \& Elektronika, n.d.)

Menurut (Azmielvita, 2010) Pemeriksaan golongan darah mempunyai berbagai manfaat dan mempersingkat waktu dalam identifikasi. Golongan darah penting untuk diketahui dalam hal kepentingan transfusi donor yang tepat serta identifikasi pada kasus kriminal.

Penelitian ini merancang sebuah alat yang dapat membaca golongan darah secara elektronik untuk memudahkan pengujian sampel darah dalam jumlah banyak. Pengujian golongan darah manusia, pada alat ini menggunakan Sistem ABO. Alat yang dirancang terdiri dari sensor cahaya yang dibangun dari LED dan LDR, sensor photodioda, serta pengolah data menggunakan Arduino Uno dan display.

Dari permasalahan diatas maka penulis ingin membuat suatu alat pendeteksi golongan darah secara elektronik, yang mana alat tersebut merupakan suatu pengembangan pembacaan suatu sampel golongan darah dengan menggunakan sensor dan rangkaian Arduino Uno. Alat ini memanfaatkan pembacaan golongan darah secara otomatis untuk membaca dan menentukan golongan darah. 
Berdasarkan identifikasi masalah diatas penulis ingin membuat alat pendeteksi golongan darah secara invasive yang memudahkan user bahkan orang awam dalam memeriksa golongan darah disaat darurat. Oleh, sebab itu alat pendeteksi golongan darah secara elektronik dapat membantu dan mempermudah kinerja tenaga medis, menambah pengetahuan dan mengenal prinsip kerja alat penedeteksi golongan darah, serta mampu mengatasi masalah tersebut.

\section{A. Maksud dan Tujuan}

Adapun maksud dari pembuatan Tugas Akhir ini sebagai berikut:

1. Merancang alat yang dapat membantu mengatasi masalah keakuratan data pada penguji atau pengamatan terhadap golongan darah.

2. Merancang alat yang dapat mendeteksi golongan darah pada manusia secara elektronik.

3. Agar dapat membantu penguji atau pengamat dalam melakukan pemeriksaan transfusi darah dan mempermudah dalam pengerjaan.

4. Sebagai referensi alat bantu untuk mempermudah kerja tenaga medis.

\section{B. Metode Penelitian}

Dalam melakukan penyusunan dan penelitian untuk mendapatkan data serta informasi, maka metode yang digunakan dalam proses pengumpulan data dilakukan sebagai berikut :

1. Metode Pengamatan (Observasi)

Dalam hal ini penulis melakukan pengamatan dan mempelajari permasalahan pada saat pengambilan sampel darah, serta melihat tahapan-tahapan yang dilakukan untuk transfusi darah di PMI.

2. Wawancara (Interview)

Untuk mendapatkan data-data secara langsung dari sumber yang mengerti sehubungan dengan pengamatan yang penulis lakukan. Dalam hal ini penulis mengajukan pertanyaanpertanyaan kepada PMI.

3. Metode Studi Pustaka

Penulis mempelajari buku-buku referensi dan jurnal untuk sebagai tambahan data serta untuk menunjang pengumpulan informasi yang dibutuhkan dan referensi yang diperoleh dari buku, jurnal, artikel maupun dari internet.

\section{Ruang Lingkup}

Adapun ruang lingkup untuk penulisan Tugas Akhir ini “Pembuatan Alat Pedeteksi Golongan Darah Berbasis Arduino Uno", diperentukan untuk mempermudah kerja tenaga medis ataupun orang yang tidak ada latar belakang ilmu medis untuk mengetahui golongan darah seseorang.

Dimulai dari proses sensor LED sebagai transmitter dan sensor photodioda, rangkaian komparator dan pengolahan data menggunakan Arduino Uno kemudian sensor akan diolah dan hasil pembacaan golongan darah akan ditampilkan pada LCD display. Dirancang untuk mengetahui golongan darah manusia secara otomatis dan cepat menggunakan metode ABO.

Adapun cara kerja alat ini adalah sampel darah yang telah ditetesi antisera dan ditempatkan pada preparat, dan dideteksi oleh optoisolator kemudian data dari optoisolator dikirimkan ke Ardunio Uno yang telah diprogramkan untuk menentukan golongan darah. Kemudian hasil dari instruksi-instruksi yang ada pada mikrokontroler Arduino Uno tersebut sehingga output nya langsung dapat ditampilkan pada LCD dan dicetak hasil pengujian golongan darah yang nanti nya tampilannya meliputi: golongan darah, yang telah diuji. gunanya untuk menjadi bukti untuk pasien yang telah melakukan pemeriksaan golongan darah di tempat klinik tersebut. pada perancangan alat ini digunakan bahasa pemograman bahasa $\mathrm{C}$.

\section{Tinjauan Umum Alat}

Alat pendeteksi golongan darah berbasis Arduino Uno adalah subjek penelitian dari alat yang dibuat. Alat ini menggunakan konsep sensor cahaya yang menggunakan 2 komponen utama yakni LED dan sensor photodioda. LED berfungsi sebagai pemancar cahaya dan photodioda berfungsi sebagai penerima cahaya. Hasil dari pembacaan respon cahaya dari 
sensor cahaya akan diolah mikrokontroller Arduino Uno untuk menentukan golongan darah sesuai dengan rumus yang telah dibuat menggunakan software Arduino IDE.

Komponen penampilan pada alat penelitian ini yakni menggunakan LCD matrix 16x2. Hasil pembacaan sensor yang diolah oleh Arduino akan ditampilkan menggunakan LCD 16x2. Selain menggunakan display LCD 16×2, alat ini juga dilengkapi dengan mesin pencetak struk yang akan mempermudah user dalam mengidentifikasi identitas serta golongan darah seseorang yang dicek.

Pada tahap pengujian alat ini nantinya akan menggunakan sebuah kaca preveret yang berfungsi untuk meletakkan sample darah yang akan diuji dan juga cairan antisera yakni antisera A dan antisera B. Cairan ini adalah komponen darah berwarna kuning yang menjadi medium sel-sel darah yang berfungsi untuk mengetes adanya proses aglutinasi atau tidak.

\section{Bahan Penelitian}

Bahan penelitian yang digunakan pada alat pendeteksi golongan darah ini adalah sebagai berikut :

1. Arduino Uno, berfungsi sebagai mikrokontroller utama pada alat penelitian yang mana di dalamnya sudah terdapat satu buah chip Atmega 328P yang berfungsi untuk penyimpanan program.

2. Sensor cahaya yang berfungsi untuk mendeteksi perbedaan golongan darah menggunakan konsep pemancar dan penerimaan cahaya.

3. LCD 16x2 yang berfungsi sebagai output penampil pengolahan data dari mikrokontroller.

4. Kaca preveret, sebagai tempat peletakkan sampel darah.

5. Cairan antisera, yang berfungsi untuk mengetes terjadinya proses aglutinasi pada sampel darah yang diambil.

6. Mesin pencetak struk digital, yang berfungsi untuk mengidentifikasi hasil pengecekan darah yang telah dilakukan.

\section{Alat Penelitian}

Dalam penelitian ini tentunya digunakan berbagai macam alat penelitian guna tercapainya suatu hasil penelitian yang nyata dan akurat. Berikut adalah beberapa alat yang digunakan dalam rencana penelitian :

1. Multimeter analog dan digital yang digunakan untuk mengukur tegangan dan arus, menguji komponen sebelum digunakan dan menguji jalur-jalur PCB untuk menghindari terjadinya short circuit (hubung singkat).

2. Software Arduino IDE yang digunakan untuk software pemrograman.

3. Alat perkakas elektronik digunakan untuk memasang komponen elektronik pada rangkaian alat penelitian, seperti: solder, timah patri (timah solder), dan atraktor.

4. Alat perkakas mekanik digunakan untuk memasang bagian mekanik atau box pada alat penelitian, seperti: obeng, tang, bor, dan gergaji.

\section{E. Blok Rangkaian Alat}

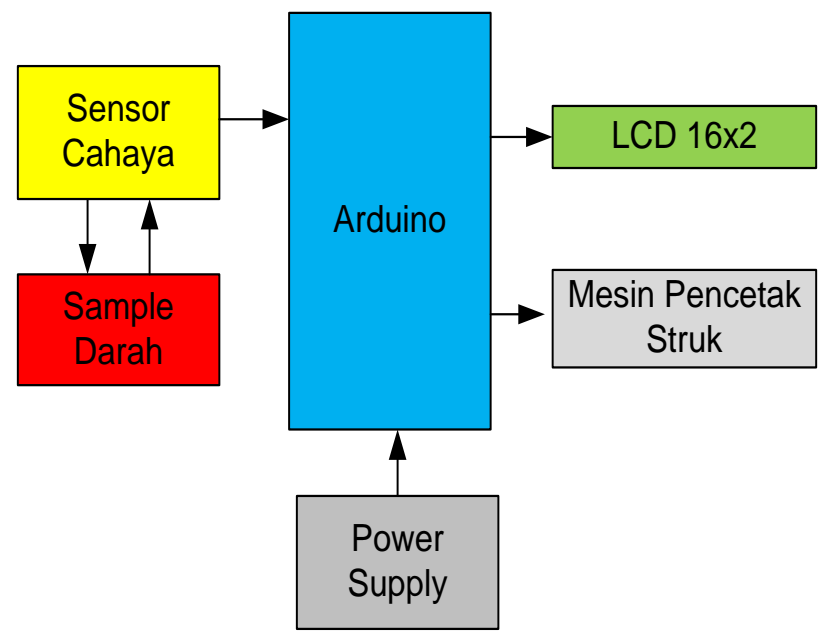

Sumber: Penulis 


\section{Gambar.III.1 Blok Diagram Sistem Alat Pendeteksi Golongan Darah}

Blok diagram sistem rangkaian alat secara umum pada alat penelitian yang dibuat, pada blok diagram sistem tersebut terdapat 6 buah blok yang masing-masing diberikan identitas dengan label dan warna yang berbeda-beda. Untuk penjelasan blok rangkaian alat ini adalah sebagai berikut:

1. Input

Komponen input ini berfungsi sebagai komponen masukan yang akan diproses terdiri dari:

a. Power Supply ( catu daya) dengan blok warna abu-abu berfungsi sebagai sumber tegangan pada alat pedeteksi golongan darah yang menyalurkan arus +12 volt ke dalam rangkaian alat.

b. Sensor dengan blok berwarna kuning yang merupakan sensor cahaya yang didalamnya terdapat 2 buah komponen utama yaitu LED dan photodioda berfungsi sebagai masukan atau input utama dari keselurahan alat yang dibuat.

2. Prosess

Prosess dengan blok warna biru muda yang merupakan komponen penting dalam sebuah alat karena sebagai pengelola data. Proses Arduino yang merupakan kontrol utama atau chip utama pada alat penelitian yang dibuat, semua perintah program akan dikelola oleh Arduino. Dalam prosess ini, penulis menggunakan Arduino Uno.

3. Output

Output adalah hasil keluaran dari semua prosess yang telah dilakukan. Dalam alat ini penulis menggunakan LCD 16x2 dengan blok warna hijau yang berfungsi sebagai penampil output dari program dan mesin pencetak struk (thermal printer) dengan blok warna abu-abu muda yang berfungsi untuk mencetak hasil pengidentifikasian golongan darah yang diuji.

4. Sampel Darah

Sampel darah dengan blok warna merah merupakan sampel darah yang mejadi objek utama pada penelitian ini. Sampel darah yang dibutuhkan adalah sampel dengan golongan darah (A, $B, A B$, dan $O)$.

\subsection{Flowchart Program}




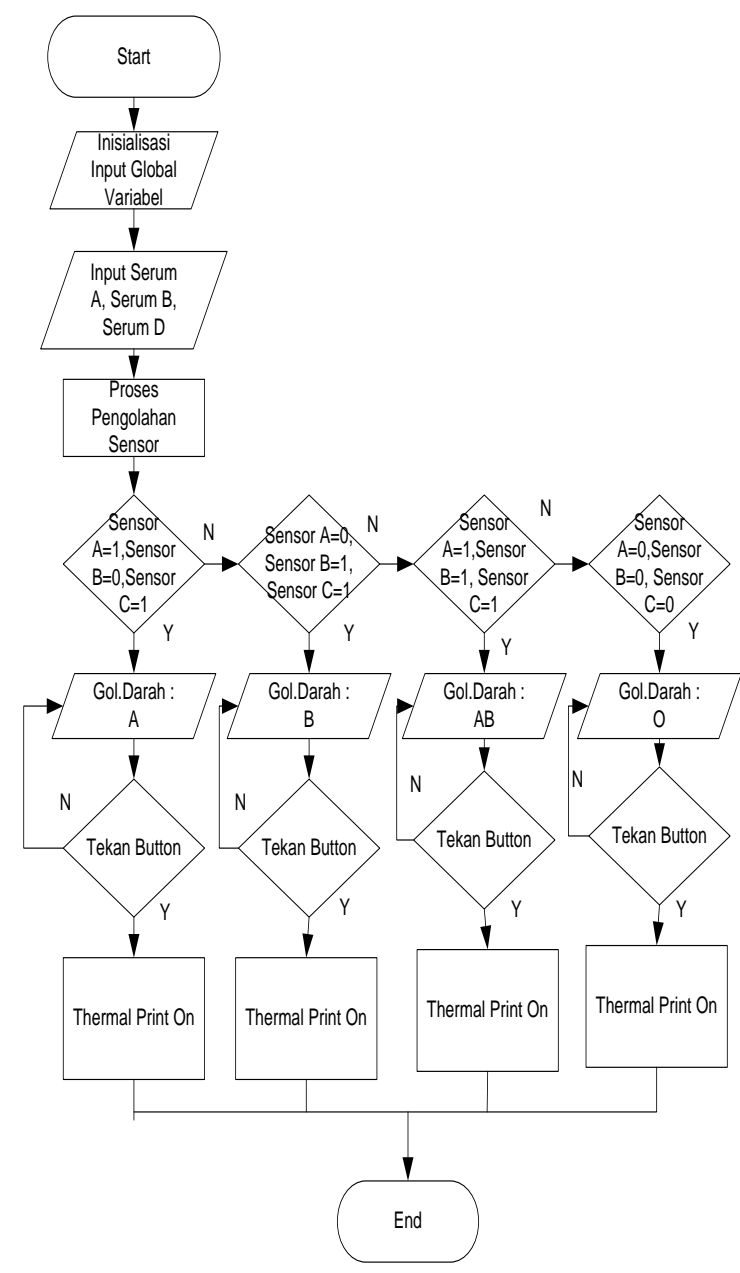

Gambar.III.9 Flowchart Program

Cara kerja alat secara keseluruhan dari alat pendeteksi golongan darah berbasis arduino ini adalah sebagai berikut. Ketika sumber tegangan (adaptor) di hubungkan dengan sumber tegangan jala-jala pln maka alat akan menyala. Rangkaian adaptor yang digunakan adalah tipe stepdown atau penurun tegangan. Ouput tegangan yang dihasilkan oleh adaptor ialah sebesar 12 volt. Tegangan 12 volt ini kemudian akan dihubungkan dengan pin input tegangan pada Arduino Uno. Ketika mikrokontroller Arduino Uno mendapat masukan tegangan, maka seluruh pin input/output akan aktif dengan kondisi yang sudah ditentukan melalui program. Langkah awal yang dilakukan ialah melakukan pengecekan sampel golongan darah yang telah diberikan cairan antisera A dan antisera B. Pada tahap ini sensor cahaya akan bekerja sesuai dengan fungsinya. Sensor cahaya akan mendeteksi sampel darah yang telah tercampur dengan masing-masing cairan anti sera. Berdasarkan prinsip kerja dari sensor cahaya dimana saat sensor cahaya mendapatkan tegangan sebesar 5 volt maka LED akan menyala. Intensitas cahaya yang dikeluarkan oleh LED diberikan hambatan berupa resistor dengan nilai resistansi $560 \mathrm{ohm}$. LED akan membaca objek dengan kondisi pantulan cahaya yang berbeda-beda, perbedaan kondisi inilah yang menjadi prinsip kerja dari sensor cahaya. Saat photodioda menerima pantulan cahaya yang terang maka hambatannya menjadi kecil yakni kurang dari nilai resistor $10 \mathrm{k}$. Sebaliknya ketika photodioda tidak menerima pantulan cahaya maka hambatannya menjadi lebih dari 10k. Objek yang digunakan disini ialah sampel darah yang masing-masing memiliki warna yang berbeda-beda. Saat sensor cahaya telah mendeteksi objek golongan darah, maka LCD akan menampilkan pesan berupa jenis golongan darah yang telah dideteksi. Pesan ditampilkan melalui dua jalur I2C yakni SDA dan SCL yang terhubung ke pin A4 dan A5 pada Arduino Uno. Pesan yang ditampilkan berupa Variabel Huruf A, B, dan C yang masing-masing menampilkan nilai ADC dari Arduino Uno dan juga menampilkan jenis golongan darah yang terdeteksi. Setelah berhasil menampilkan pesan berupa jenis golongan darah, kemudian mesin thermal print pencetak struk akan mencetak hasil dari pembacaan golongan 
darah sesuai dengan yang tertampil di LCD. Namun mesin thermal print ini hanya akan mengeluarkan struk ketika tombol push button yang terhubung ke Pin Analog 3 ditekan oleh user atau pengguna.

\subsection{Kesimpulan}

Berdasarkan hasil penelitian dan pembahasan yang telah dilakukan, maka telah berhasil dibuat alat penelitian dengan judul "Alat Pendeteksi Golongan Darah Berbasis Arduino". Dari penelitian yang telah dibuat maka didapatkan kesimpulan sebagai berikut :

Alat dapat mendeteksi perbedaan golongan darah $A, B, A B$, dan $O$ dengan menggunakan metode konversi nilai adc ke dalam tegangan. Perbedaan nilai sensor yang cukup signifikan merupakan parameter utama untuk kondisi pada program. Dari hasil percobaan yang telah dilakukan range nilai tegangan untuk kondisi sensor yang mendeteksi adanya penggumpalan darah ialah $(>=0.12$ volt dan $<=1.10 \mathrm{volt}$ ) dan range nilai tegangan untuk kondisi sensor yang mendeteksi tidak adanya penggumpalan darah ialah $(=>1.10$ volt dan $<=3.10 \mathrm{volt}$ ).

Hasil dari pengujian masing-masing rangkaian input dan output sudah menunjukkan hasil yang baik dimana dari percobaan dasar yang telah dilakukan pada masing-masing rangkaian input dan output menunjukkan hasil yang normal.

\section{REFERENSI}

Agus Purnama. (2018). Sensor Photodioda. Elektronika Dasar. Retrieved from https://elektronika-dasar.web.id/sensor-photodioda/

Andrianto, H., \& Darwaman, A. (2017). Arduino Belajar Cepat dan Pemograman (cetakan ke). Bandung: Informatika Bandung.

Andrianto Heri, D. A. (2017). Arduino Belajar Cepat Dan Pemrograman (cetakan ke). Bandung: Informatika Bandung.

Dickson Kho. (2019). pengertian LED dan cara kerjanya, Pengertian dan Fungsi Induktor beserta Jenis-jenisnya. Teknik Elekttronika. Retrieved from https://teknikelektronika.com/pengertian-led-light-emitting-diode-cara-kerja/

Didiek Prasetya M.sn. (2018). Pengertian Perangkat Lunak(Software) Komputer dan Fungsinya. Retrieved from https://nanopdf.com/download/pengertian-perangkat-lunak-software_pdf

Drs. Imam Muda N, S. T. M. . (2013). Elektronika Dasar (1st ed.). Malang: Gunung Samudera PT.Book Mart Indonesia.

Hakiem Ilmiawan. (2015). TokoTeknologi: Electronics Design \& Repair (1st ed.; Hakiem Ilmiawan, Ed.). https://doi.org/Tokoteknologi

Inggi, L., \& Elektronika, L. (n.d.). Rancangan sistem alat pendeteksi golongan darah. 2-5.

Muhammad Alfatih. (2017). Printer Thermal. Retrieved from bengkel printer.com website: http://bengkelprinter.com/printer-thermal\#

Musbikhin. (2011). Pengertian Sensor Dan Macam -macam Sensor. Retrieved from Musbikhin.com website: https://www.musbikhin.com/pengertian-sensor-dan-macammacam-sensor/

Permana, B., \& Kom, S. (2007). Pe rang k a t Ke r a s Ko m p u te r. 1-17.

Priyatno Duwi. (2012). Panduan Lengkap Komputer:PC,Laptop,Tablet (1st ed.; Z. Priyatno Duwi, Yulianto Harris Syamsi, Daningsih Sherli, Ed.). Retrieved from https://books.google.co.id/books?id=Yz2xDAAAQBAJ\&printsec=frontcover\&hl=id\&source =gbs_vpt_buy\#v=onepage\&q\&f=false

(Priyatno Duwi, 2012)Agus Purnama. (2018). Sensor Photodioda. Elektronika Dasar. Retrieved from https://elektronika-dasar.web.id/sensor-photodioda/

Andrianto, H., \& Darwaman, A. (2017). Arduino Belajar Cepat dan Pemograman (cetakan ke). Bandung: Informatika Bandung.

Andrianto Heri, D. A. (2017). Arduino Belajar Cepat Dan Pemrograman (cetakan ke). Bandung: Informatika Bandung.

Dickson Kho. (2019). pengertian LED dan cara kerjanya, Pengertian dan Fungsi Induktor beserta Jenis-jenisnya. Teknik Elekttronika. Retrieved from https://teknikelektronika.com/pengertian-led-light-emitting-diode-cara-kerja/

Didiek Prasetya M.sn. (2018). Pengertian Perangkat Lunak(Software) Komputer dan Fungsinya. 
Retrieved from https://nanopdf.com/download/pengertian-perangkat-lunak-software_pdf Drs. Imam Muda N, S. T. M. . (2013). Elektronika Dasar (1st ed.). Malang: Gunung Samudera PT.Book Mart Indonesia.

Hakiem Ilmiawan. (2015). TokoTeknologi: Electronics Design \& Repair (1st ed.; Hakiem Ilmiawan, Ed.). https://doi.org/Tokoteknologi

Inggi, L., \& Elektronika, L. (n.d.). Rancangan sistem alat pendeteksi golongan darah. 2-5.

Muhammad Alfatih. (2017). Printer Thermal. Retrieved from bengkel printer.com website: http://bengkelprinter.com/printer-thermal\#

Musbikhin. (2011). Pengertian Sensor Dan Macam -macam Sensor. Retrieved from Musbikhin.com website: https://www.musbikhin.com/pengertian-sensor-dan-macammacam-sensor/

Permana, B., \& Kom, S. (2007). P e ra ng k a $\mathrm{t}$ Ke ra s Ko m p u te r. 1-17.

Priyatno Duwi. (2012). Panduan Lengkap Komputer:PC,Laptop,Tablet (1st ed.; Z. Priyatno Duwi, Yulianto Harris Syamsi, Daningsih Sherli, Ed.). Retrieved from https://books.google.co.id/books?id=Yz2xDAAAQBAJ\&printsec=frontcover\&hl=id\&source =gbs_vpt_buy\#v=onepage\&q\&f=false 